\title{
Piecewise modeling of the associations between dry period length and milk, fat, and protein yield changes in the subsequent lactation
}

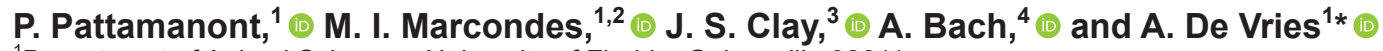 \\ ${ }^{1}$ Department of Animal Sciences, University of Florida, Gainesville 32611 \\ ${ }^{2}$ Department of Animal Science, Federal University of Vicosa, Vicosa, Minas Gerais 36570-001, Brazil \\ ${ }^{3}$ Dairy Records Management Systems, North Carolina State University, Raleigh 27603 \\ ${ }^{4}$ Catalan Institution for Research and Advanced Studies (ICREA), 08010 Barcelona, Spain
}

\begin{abstract}
Our objective was to develop predictive models of 305-d mature-equivalent milk, fat, and protein yields in the subsequent lactation as continuous functions of the number of days dry (DD) in the current lactation. In this retrospective cohort study with field data, we obtained DHIA milk recording lactation records with the last DD in 2014 or 2015. Cows included had DD from 21 to $100 \mathrm{~d}$. After editing, 1,030,141 records from cows in 7,044 herds remained. Three parity groups of adjacent (current, subsequent) lactations were constructed. We conducted all analyses by parity group and yield component. We first applied control models to pre-adjust the yields in the subsequent lactation for potentially confounding effects. Control models included the covariates mature-equivalent yield, days open, somatic cell score at $180 \mathrm{~d}$ pregnant, daily yield at $180 \mathrm{~d}$ pregnant, and a herd-season random effect, all observed in the current lactation. Days dry was not included. Second, we modeled residuals from control models with smooth piecewise regression models consisting of a simple linear, quadratic, and another simple linear equation depending on DD. Yield deviations were calculated as differences from predicted matureequivalent yield at $50 \mathrm{DD}$. For validation, predictions of yield deviations from piecewise models by DD were compared with predictions from local regression for the DHIA field records and yield deviations reported in 38 experimental and field studies found in the literature. Control models reduced the average root mean squared prediction error by approximately 21\%. Yield deviations were increasingly more negative for DD shorter than $50 \mathrm{~d}$, indicating lower yields in the subsequent lactation. For short DD, the decrease in 305-d matureequivalent milk yield ranged from 43 to $53 \mathrm{~kg}$ per DD.
\end{abstract}

Received February 13, 2020

Accepted September 1, 2020.

*Corresponding author: devries@ufl.edu
For mature-equivalent fat and protein yields, decreases were between 1.28 and $1.71 \mathrm{~kg}$ per DD, and 1.06 and $1.50 \mathrm{~kg}$ per DD, respectively. Yield deviations often were marginally positive and increasing for $\mathrm{DD}>50$, so that the highest yield in the subsequent lactation was predicted for 100 DD. For long DD, the 305-d matureequivalent milk yield increased at most $4.18 \mathrm{~kg}$ per DD. Patterns in deviations for fat and protein yield were similar to those for milk yield deviations. Predictions from piecewise models and local regressions were very similar, which supports the chosen functional form of the piecewise models. Yield deviations from field studies in the literature typically were decreasing when DD were longer, likely because of insufficient control for confounding effects. In conclusion, piecewise models of mature-equivalent milk, fat, and protein yield deviations as continuous functions of DD fit the observed data well and may be useful for decision support on the optimal dry period length for individual cows.

Key words: dry period, segmented, model, prediction

\section{INTRODUCTION}

The dry period at the end of gestation is important for involution and redevelopment of mammary epithelial cells to prepare the mammary gland for the upcoming lactating period (Capuco et al., 1997; Zhao et al., 2019). Consequently, a short or omitted dry period reduces milk yield in the subsequent lactation (Bachman and Schairer, 2003; van Knegsel et al., 2013). A short dry period also means that more milk is harvested before calving. The dry period length affects the energy balance, health, and fertility after calving (Grummer and Rastani, 2004; van Knegsel et al., 2013). In the United States, an average 60-d dry period commonly has been recommended (Grummer and Rastani, 2004; USDA, 2016) and has also been observed (Kuhn et al., 2005a). In Canada, average dry period lengths in 10 provinces ranged from 65 to $81 \mathrm{~d}$ (Lactanet, 2020).

In practice, many dairy farmers vary dry period lengths on purpose, either for a group of cows or based 
on individual characteristics. In a USDA survey, more than $80 \%$ of dairy farmers dried some cows off based on a minimum milk production level, and $50 \%$ dried cows off early to treat mastitis (USDA, 2016). In a German survey, dry-off decisions depended on the cow's and farm's needs (Bertulat et al., 2015). Field data show large ranges of dry period lengths (Kuhn et al., 2005a; Pinedo et al., 2011; Atashi et al., 2013). Economics studies also indicate that optimal dry period lengths depend on farm and cow characteristics (Dias and Allaire, 1982; Steeneveld et al., 2014). Further finetuning of optimal dry period lengths requires a decision interval of $1 \mathrm{wk}$ or less, depending on the ability of farm management.

Optimal target dry period lengths for individual cows are difficult to discern without good decision aids. To develop such decision aids, prediction equations of milk, fat, and protein yield deviations in the subsequent lactation based on continuous functions of days dry (DD) are useful. Typically, randomized controlled (experimental) studies have evaluated only a small number of dry period lengths; for example, 3 categories consisting of continuous milking, short DD, and conventional DD. We did not find experimental studies for DD longer than $71 \mathrm{~d}$, although longer dry period lengths are not uncommon and could be optimal.

Field studies have grouped dry period lengths into more categories (19 in Funk et al., 1987; 16 in Kuhn et al., 2005a; 13 in Kuhn et al., 2007; 14 in Hossein-Zadeh and Mohit, 2013), with average intervals of 5 to $10 \mathrm{~d}$ between categories. In these field studies, estimates of yield deviations in categories with fewer observations tend to fluctuate more. These studies did not provide prediction equations that would smooth out such fluctuations and would provide predictions of yield deviations for days within the categories.

Dias and Allaire (1982) used cubic polynomial regression to model the relationship between yield deviations and DD based on field data. Kuhn and Hutchison (2005) reasoned that the relationship between yield deviations for the range of short to long DD was difficult to model precisely with cubic polynomial regression.

Predictions of yield deviations due to variations in dry period length obtained from field studies need to be corrected for differences in cow performance that are known to affect yield in the subsequent lactation, such as 305-d milk yield (Kuhn and Hutchison, 2005), days open and SCC (Grummer and Rastani, 2004; Kuhn et al., 2005b). In addition, Bach and Pont (2017) showed some evidence that shortening DD below $60 \mathrm{~d}$ compromises milk yield in the subsequent lactation, and this effect is exacerbated when milk yield at dry-off is high. Ideally, decision aids include covariates that improve the prediction of yield deviations based on individual cow characteristics.

We hypothesized that we could develop good-fitting prediction equations of mature-equivalent yield deviations in the subsequent lactation based on continuous DD. The second hypothesis was that yield deviations in the subsequent lactation were associated with level of yield in the current lactation. Therefore, our main objective was to develop and validate equations that predict deviations in milk, fat, and protein mature-equivalent yield in the subsequent lactation as a function of DD in the current lactation. A secondary objective was to estimate how yield deviations in the subsequent lactation depended on yield and DD in the current lactation.

\section{MATERIALS AND METHODS}

\section{Data Description and Editing}

For this observational cohort study, unfiltered DHIA Holstein lactation records from cows in herds located in 40 states across the US were obtained from Dairy Records Management Systems (DRMS, Raleigh, NC). New records were created by concatenating 2 adjacent lactations for each cow, with the dry period of interest in between. The 3 groups of adjacent lactations were parity 1 and 2 (par12), parity 2 and 3 (par23), and parity 3 and greater (par3+). The lactation before the dry period of interest is referred to as the current lactation, and the lactation after calving as the subsequent lactation. Only records with the last day dry in 2014 or 2015 were kept.

Variable Selection. We used mature-equivalent milk (MILKME), fat (FATME), and protein (PROTME) yields as measures of lactational yield. Matureequivalent yields are 305-d actual or projected lactation yields, adjusted for DIM, milking frequency, season of calving, location, and age to that of a mature cow (DRMS, 2018). In addition to the benefits of controlling for these factors, the mature-equivalent yields are also less sensitive to the effect of culling compared with actual yields in the subsequent lactation. Further, the number of records with predicted 305-d actual milk yields was approximately one-third smaller than the number of records with mature-equivalent yields in our data set. Unless the cow is mature and milked 3 times per day, the mature-equivalent yield will be greater than the actual 305-d lactation yield. We also used mature-equivalent yields in the subsequent lactation as response variables. As is common in the US, yields are expressed by weight $(\mathrm{kg})$ in this study. Yield refers to milk, fat, or protein yield, as will be clear from the context. 
Yield in the subsequent lactation depends on performance in the current lactation, such as gestation length (Foote, 1981; Mur-Novales et al., 2018), lactational milk yield (e.g., Kuhn et al., 2005a; Pinedo et al., 2011; Cermakova et al., 2014), SCC at dry-off (Gott et al., 2017), milk yield at dry-off (Bach and Pont, 2017), and DIM at dry-off (Gill and Allaire, 1976; O'Connor and Oltenacu, 1988; Weber et al., 2015). Results from field studies could be vulnerable to influences by unpredictable confounding factors. Therefore, we aimed to control for the 6 current-lactation variables mature-equivalent yield, days open (days from calving to conception), gestation length, SCS at $180 \mathrm{~d}$ pregnant, daily yield at $180 \mathrm{~d}$ pregnant, and herd-season. The date of $180 \mathrm{~d}$ pregnant was determined from the date of insemination that resulted in the pregnancy, as provided to us by DRMS. We used predicted yields at $180 \mathrm{~d}$ pregnant as an estimate close to the timing of the first dry-off decision.

Observations for SCS and the 3 daily yield variables (milk, fat, protein) at $180 \mathrm{~d}$ pregnant were not available in the data set but were estimated as follows. Using all records, we regressed these 4 variables on DIM in the range of 150 to 350 DIM for each of the 3 parity groups, using simple linear regressions. The linear regression coefficients are changes per DIM. We then used the linear regression coefficients to predict the values at the DIM equal to $180 \mathrm{~d}$ pregnant, using the DIM and last test day yield before dry-off as the base. A year was divided into 4 seasons (January to March, April to June, July to September, and October to December). To investigate multicollinearity, Spearman correlations were calculated with the procedure CORR in SAS 9.4 (SAS Institute Inc., 2013).

Data Filtering. We kept records where 4,000 $\leq$ MILKME $\leq 20,000 \mathrm{~kg}, 100 \leq \mathrm{FATME} \leq 1,000 \mathrm{~kg}$, and $100 \leq$ PROTME $\leq 1,000 \mathrm{~kg}$. In addition, we required $0.80 \leq$ FATME/PROTME $\leq 1.60,0.025 \leq$ FATME $/$ MILKME $\leq 0.050,0.022 \leq$ PROTME/MILKME $\leq$ 0.038 , days open $\geq 40 \mathrm{~d}$, gestation length $\geq 265 \mathrm{~d}, 610$ $<$ age at first calving $<936 \mathrm{~d}$, and calving interval of the current lactation $<600 \mathrm{~d}$. Further, cows had to have at least 6 test day observations in the current lactation and a last test day date that was fewer than $60 \mathrm{~d}$ before the reported dry-off date. The reported dry-off date is the date that all milking was stopped. Finally, we required $21 \leq \mathrm{DD} \leq 100$ for individual cow records. To be considered in the study, a herd had to have at least 5 cows present in a season after these data filters were applied. After data filtering, the number of remaining records for par12, par23, and par3+ were 496,547, 289,959 , and 243,635 , respectively. These records were from 7,044 herds.
Descriptive statistics for selected variables are summarized by 8 categories of DD in Tables 1, 2, and 3 . Tables 1 to 3 make clear that the levels of these variables in the current lactation vary with $\mathrm{DD}$ category. Therefore it was necessary to control for current lactation performance, to partition out the association between DD and yields in the subsequent lactation.

\section{Modeling}

Approach. We developed piecewise (segmented) regression models that spanned the range from 21 to 100 DD. Covariates were not included in these piecewise models, mainly because of convergence problems. Instead, we developed control models that included all covariates except DD. All covariates were observed in the current lactation. All response variables were mature-equivalent yields observed in the subsequent lactation. We then used the residuals from these models as response variables in the piecewise models. All modeling was done separately for each parity group and each yield component (milk, fat, protein).

Scenarios. In addition to the 3 scenarios in which we estimated parameters for piecewise models for MILKME, FATME, and PROTME (full scenarios) per parity group, we made 9 additional scenarios with only low, medium, or high levels for yield variables (limited scenarios). These 9 limited scenarios were created to investigate the effects of the level of these yields in the current lactation on yields in the subsequent lactation, as a proxy for including covariates in the piecewise models. Limits for these 9 scenarios were chosen to include approximately $25 \%$ of the observations in the low and high categories and the remainder in the medium categories. The 3 low categories included MILKME $<11,500 \mathrm{~kg}$ or FATME $<425 \mathrm{~kg}$ or PROTME $<350 \mathrm{~kg}$. The 3 high categories include MILKME $\geq 14,500 \mathrm{~kg}$ or FATME $\geq 535 \mathrm{~kg}$ or PROTME $\geq 430 \mathrm{~kg}$. The 3 medium categories included the remainder of the observations. In total we had $3 \times 3 \times 4=36$ scenarios.

Control Modeling. We fitted each response variable (MILKME, FATME, and PROTME) with a linear model that included the 5 covariates gestation length, days open, SCS at $180 \mathrm{~d}$ pregnant, daily yield at 180 d pregnant, and mature-equivalent yield. Covariate yield variables were for the same component (milk, fat, or protein) as the response variables. For example, if the response variable was FATME in the subsequent lactation, then the corresponding yield covariates were FATME in the current lactation and fat yield at 180 $\mathrm{d}$ pregnant in the current lactation. We included their main terms, quadratic terms, and 2-way interactions. Herd-season was added as the sixth independent vari- 


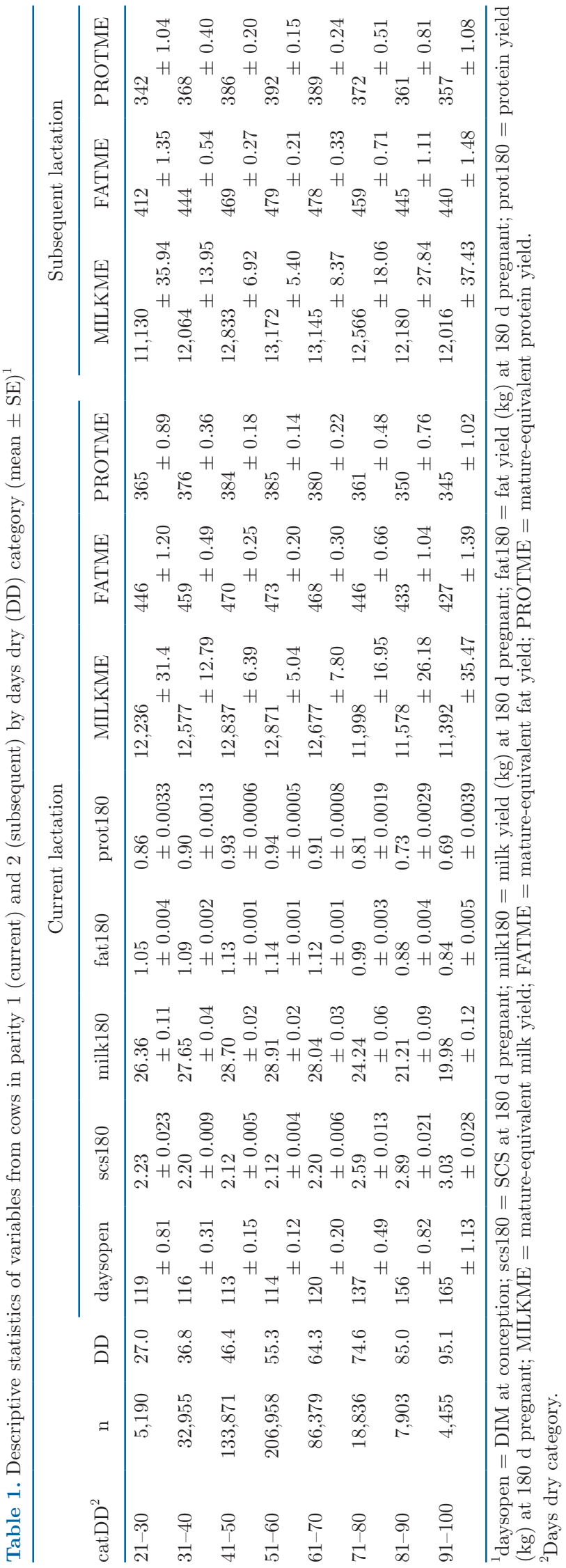

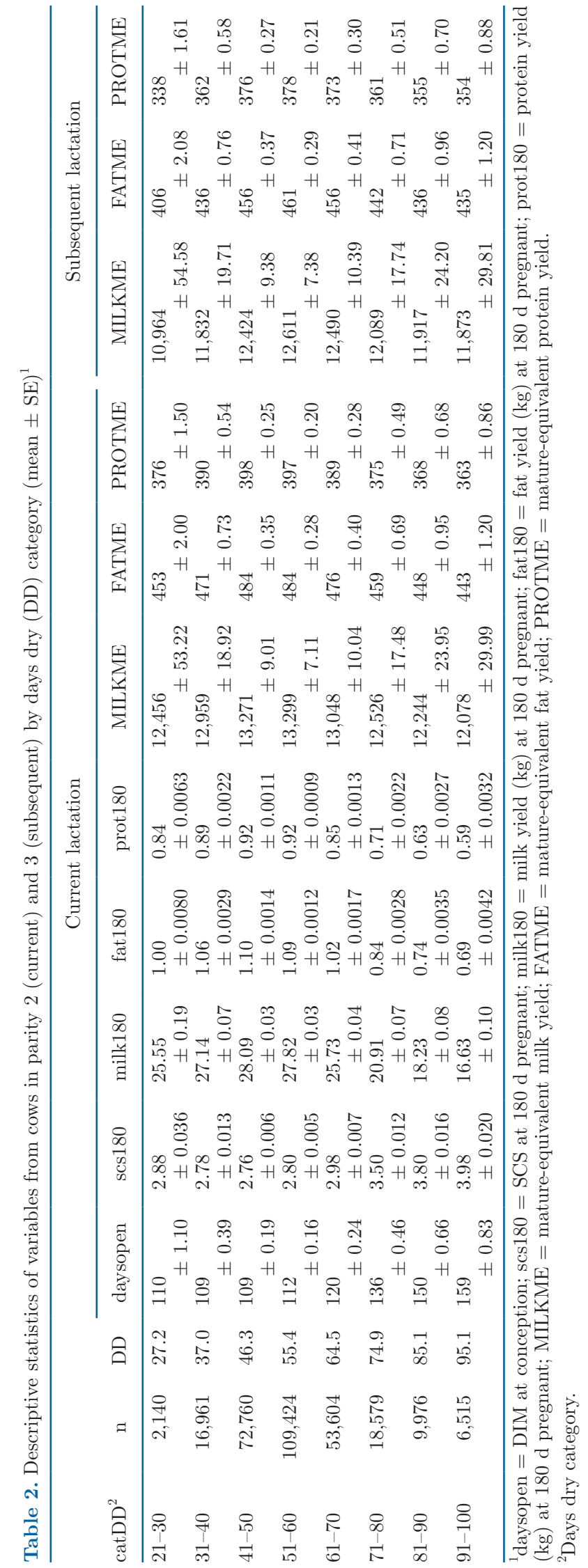




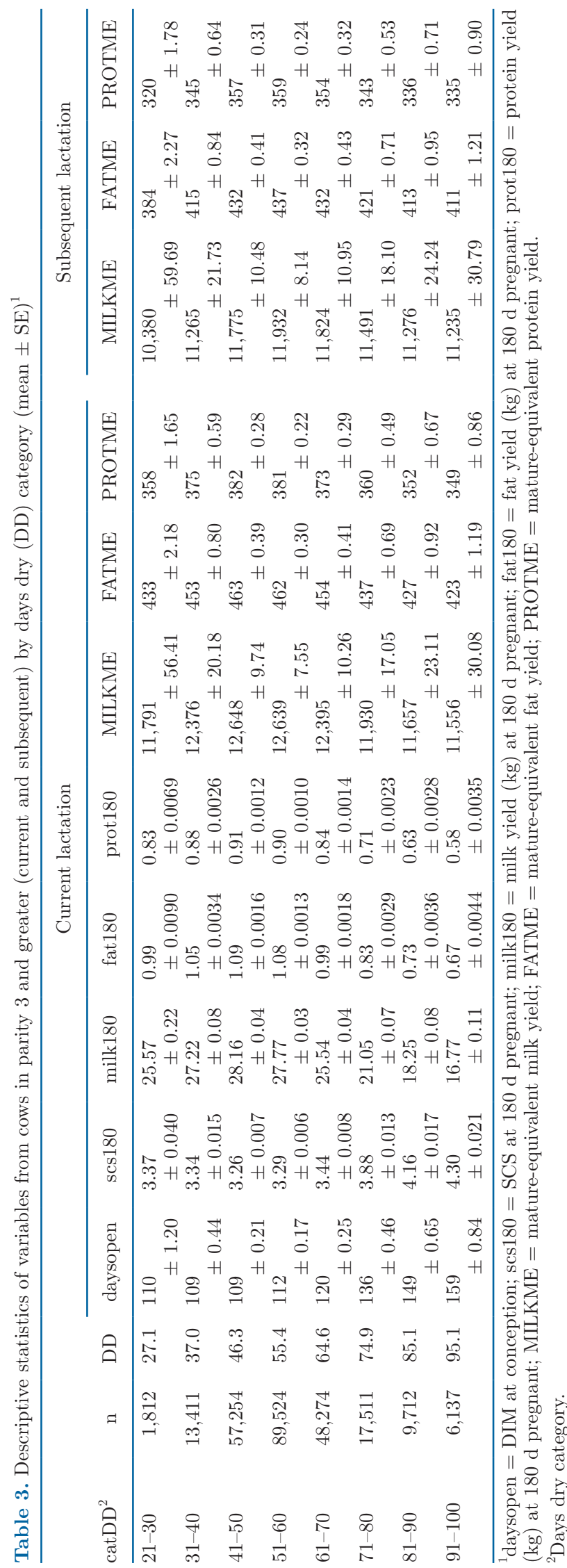

able and included as a random effect. Modeling was done with procedure MIXED in SAS, and the residuals were checked for nonrandom patterns and saved for the piecewise modeling.

Piecewise Modeling. After investigating many functional forms, we chose a 2-knot piecewise regression model that existed of a linear equation for short $\mathrm{DD}$, a quadratic equation around conventional DD, and another linear equation for long DD. The 3 equations were joined at the 2 knots. In addition, we required that the equations were smooth at the knots. This was accomplished by requiring that the first-order derivatives with respect to DD of both equations that joined at a knot were equal. The 2 -knot piecewise model was as follows:

$$
\begin{gathered}
\mathrm{y}=\mathrm{a}+\mathrm{d} 1 \times \mathrm{x}, \text { if } \mathrm{x}<\mathrm{x} 1 \\
\mathrm{y}=\mathrm{a}+\mathrm{d} 1 \times \mathrm{x} 1+\mathrm{b} \times(\mathrm{x}-\mathrm{x} 1)+\mathrm{c} \\
\times(\mathrm{x} \times \mathrm{x}-\mathrm{x} 1 \times \mathrm{x} 1), \text { if } \mathrm{x} \geq \mathrm{x} 1 \text { and } \mathrm{x} \leq \mathrm{x} 2 \\
\mathrm{y}=\mathrm{a}+\mathrm{d} 1 \times \mathrm{x} 1+\mathrm{b} \times(\mathrm{x} 2-\mathrm{x} 1)+\mathrm{c} \\
\times(\mathrm{x} 2 \times \mathrm{x} 2-\mathrm{x} 1 \times \mathrm{x} 1)+\mathrm{d} 2 \\
\times(\mathrm{x}-\mathrm{x} 2), \text { if } \mathrm{x}>\mathrm{x} 2
\end{gathered}
$$

where $\mathrm{x}$ is $\mathrm{DD}$; $\mathrm{x} 1$ and $\mathrm{x} 2$ are the DD at the knots; $\mathrm{y}$ is the residual for a response variable after control modeling; and $\mathrm{a}, \mathrm{b}, \mathrm{c}, \mathrm{d} 1, \mathrm{~d} 2, \mathrm{x} 1$, and $\mathrm{x} 2$ are parameters. The parameters $\mathrm{a}, \mathrm{b}, \mathrm{d} 2, \mathrm{x} 1$, and $\mathrm{x} 2$ were determined by the procedure NLIN in SAS. To force smoothness at the 2 knots, we set $\mathrm{c}=(\mathrm{d} 2-\mathrm{b}) /(2 \times \mathrm{x} 2)$ and $\mathrm{d} 1=\mathrm{b}+2 \times$ $\mathrm{c} \times \mathrm{x} 1$ within procedure NLIN. Starting values were a $=-100, \mathrm{~b}=100, \mathrm{x} 1=35, \mathrm{x} 2=55$, and $\mathrm{d} 2=-1$. We slightly adjusted the "a" parameters for each scenario such that the predicted yield at $50 \mathrm{DD}$ was $0 \mathrm{~kg}$ for fair comparisons. Yields predicted for other DD are referred to as yield deviations from 50 DD.

Local Regression. We performed locally estimated scatterplot smoothing with the procedure LOESS in SAS to show patterns in average yield deviations per DD. The LOESS procedure automatically finds the optimal smoothing parameter. Local regression patterns were used to visually validate the fit of the piecewise models.

Goodness of Fit. We measured goodness of fit of the models by the root mean square error (RMSE) of predicted and observed yields (Shmueli, 2010). We measured the RMSE of the original yield observations before control modeling, and of the residuals after control modeling, and again of the residuals after piecewise modeling. This resulted in 3 RMSE per scenario. The RMSE were calculated with the procedure REG in SAS. 


\section{Literature Review on Yield Deviations}

We conducted a review of reports that published changes in milk, fat, or protein yield in relation to changes in DD. The purpose of this review was to compare and validate the modeling results of our study with data reported in the literature. We used 3 criteria for selecting the studies. First, publication year was from 1980 to 2019. Second, the response variable was lactational yield of cows that completed the lactation or 305-d yield in the subsequent lactation. Third, the yield in the subsequent lactation was at least adjusted for yield in the current lactation, although it was not always clear how this adjustment was accomplished. Reports were separated into experimental and field studies. We also separated studies of primiparous and multiparous cows in the current lactation.

Deviations were calculated as differences from the yield at the reference DD of each study, which was the control treatment of conventional DD $(\sim 60 \mathrm{~d}$, experimental studies) or the category that included the conventional 60 DD (field studies). Yield deviations for experimental and field studies were plotted separately by the average DD of each category within a study. We used the default LOESS function in R ( $\mathrm{R}$ Core Team, 2019) to perform locally estimated scatterplot smoothing and show patterns of yield deviations. These patterns were visually compared with the results of the piecewise models.

\section{RESULTS}

\section{Association of Days Dry and Variables Used in Model Building}

Cows in par12, par23, and par3+ had the following mean values in the current lactation: DD: 54.5, 56.7, and $57.5 \mathrm{~d}$; MILKME: $12,735,13,106$, and 12,455 kg; FATME: 468, 478, and $456 \mathrm{~kg}$; PROTME: 381, 392, and $376 \mathrm{~kg}$; days open: 117, 116, and $117 \mathrm{~d}$; fat yield at $180 \mathrm{~d}$ pregnant: $1.12,1.04$, and $1.02 \mathrm{~kg}$; protein yield at $180 \mathrm{~d}$ pregnant: $0.92,0.87$, and $0.86 \mathrm{~kg}$; milk yield at 180 d pregnant: $28.21,26.42$, and $26.24 \mathrm{~kg}$; and SCS at 180 d pregnant: $2.18,2.92$, and 3.42 . Average SCC at $180 \mathrm{~d}$ pregnant were $146,202,220,075$, and 322,475 cells/mL. Days in milk at dry-off date were 340, 337, and $338 \mathrm{~d}$. Daily milk yields at $14 \mathrm{~d}$ before the dryoff date were 27.2, 24.3, and $23.7 \mathrm{~kg}$. Mean gestation lengths were 278, 279, and $279 \mathrm{~d}$. Mean values in the subsequent lactation were as follows: MILKME: 12,932, 12,410, and 11,750 kg; FATME: 472, 454, and $430 \mathrm{~kg}$; PROTME: 386,373 , and $354 \mathrm{~kg}$. Standard errors were generally less than $1 \%$ of the means.
Tables 1 to 3 show the associations between the 8 categories of $\mathrm{DD}$ and variables that were used in the control models for the 3 parity groups. Trends across DD categories were similar for the 3 groups. Most cows were in the 51 to $60 \mathrm{DD}$ category, with fewer cows in shorter and longer DD categories. The best performance (fewest days open and lowest SCS at $180 \mathrm{~d}$ pregnant, and highest milk, fat, and protein yields) were in the 41 to 50 or 51 to $60 \mathrm{DD}$ categories, except days open in the par3+ group, which was the lowest in the 31 to 40 DD category.

Cows in the 91 to 100 DD category had at least 50 more days open and at least 137,000 more cells $/ \mathrm{mL}$ (0.91 greater score) than those in the best categories. Cows in the highest DD category also produced at least $8.9 \mathrm{~kg}$ less milk, $0.30 \mathrm{~kg}$ less fat, and $0.25 \mathrm{~kg}$ less protein at $180 \mathrm{~d}$ pregnant than those in the best categories. Mature-equivalent yields in the current lactation were at least $1,092 \mathrm{~kg}$ of milk, $40 \mathrm{~kg}$ of fat, and $33 \mathrm{~kg}$ of protein lower in the highest DD category. Yield differences in the lowest DD category (21-30 DD) were smaller. Shorter DD were associated with shorter gestation lengths ( $274 \mathrm{~d}$, not shown in table), which implies that DD were partly shortened because calving occurred earlier, not due to delayed dry-off.

Mature-equivalent yields in the subsequent lactation were the highest in the 51 to $60 \mathrm{DD}$ category for the 3 parity groups. Yield losses were greatest in the 21 to 30 DD category and approximately double the losses of those in the current lactation for this category. Yield losses in the 91 to 100 DD category were approximately half of the losses in the 21 to $30 \mathrm{DD}$ category.

\section{Control Modeling}

Control models for subsequent lactation matureequivalent yield (milk, fat, or protein) were built with the 5 covariates gestation length, days open, SCS at 180 d pregnant, daily yield at $180 \mathrm{~d}$ pregnant, and matureequivalent yield. Herd-season was added as a random effect. Correlations between these variables within the 3 scenarios with full models for milk, fat, and protein yields varied between -0.39 and $0.60(P<0.001)$. The most negative correlations were between SCS at $180 \mathrm{~d}$ pregnant and yields at $180 \mathrm{~d}$ pregnant. The most positive correlations were between mature-equivalent yield and yield at $180 \mathrm{~d}$ pregnant. Correlations within milk, fat, and protein scenarios were similar. We concluded that the 5 covariates were not highly correlated and therefore were included in the control models.

All control models included 21 terms, including intercept, main and quadratic terms, and 2-way interactions. All 5 main terms were not $0(P<0.05)$ in at least 
1 of the models. Somatic cell score at $180 \mathrm{~d}$ pregnant was most often not significant. We did not remove any nonsignificant terms, because our interest was in the residuals of these models.

The coefficient of determination $\left(\mathrm{R}^{2}\right)$ of the 3 control models for the full scenarios varied from 49 to $56 \%$ and was similar for the milk, fat, and protein yield models (Table 4). The $\mathrm{R}^{2}$ was lower for the models of the limited scenarios, which ranged from 22 to $45 \%$. Models for par12 had the highest $\mathrm{R}^{2}$. Before control modeling, the RMSE varied from 1,875 to $2,514 \mathrm{~kg}$ for MILKME, 74 to $98 \mathrm{~kg}$ for FATME, and 54 to $74 \mathrm{~kg}$ for PROTME. After control modeling, the RMSE varied from 1,550 to $1,992 \mathrm{~kg}$ for MILKME, 58 to $78 \mathrm{~kg}$ for FATME, and 54 to $72 \mathrm{~kg}$ for PROTME. The average reduction was $21 \%$. The 3 full scenarios had the greatest reductions in RMSE due to control modeling (Table 4). Thus, the RMSE of mature-equivalent yields remained large after control modeling.

\section{Piecewise Modeling}

All piecewise regression models converged. Parameters of the piecewise models are shown in Table 5 (MILKME), Table 6 (FATME), and Table 7 (PROTME). Tables 5 to 7 also show yield deviations at 25 and 75 DD. The optimal knots $\mathrm{x} 1$ and $\mathrm{x} 2$ varied little from the initial values of 35 and $55 \mathrm{DD}$. The distance of typically more than $15 \mathrm{~d}$ between both knots resulted in the appearance of gradual smooth connections between the left and the right linear equation (Figure 1). All piecewise models predicted greatly reduced yields for short $\mathrm{DD}$ and slower, but increasing, yields for longer DD $(\mathrm{d} 2>0)$, except for one high PROTME scenario (d2 $<0$, par12). This exception led to a negative deviation at $75 \mathrm{DD}$, whereas all other deviations at $75 \mathrm{DD}$ were positive. Therefore, the DD that predicted the greatest yield in the subsequent lactation was generally for the longest DD considered.

The limited scenarios (low, medium, or high yield) predicted smaller deviations of yields in the subsequent lactation for short DD when the yields in the current lactation were lower. This was true for all 3 parity groups. The only exception was a scenario of medium MILKME (par3+), which had more negative deviations at shorter DD and more positive deviations at longer DD.

Figure 1 shows mature-equivalent yield deviations for milk, fat, and protein yields for the full scenarios. Each graph includes the average residuals of the control models, and predictions of the piecewise model and the local regression per DD. The average residuals for short and long DD vary more than for conventional DD, due to fewer observations for short and long DD. The pre-

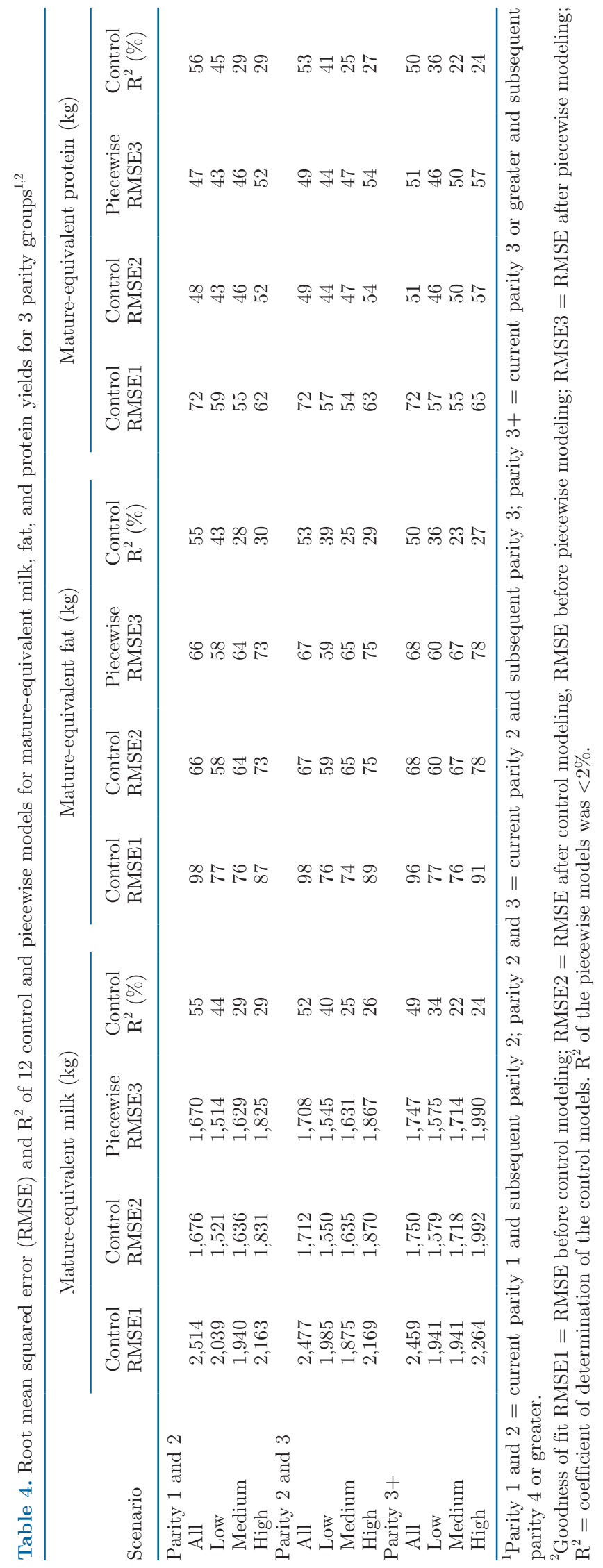


Pattamanont et al.: MILK YIELD AND DRY PERIOD LENGTH
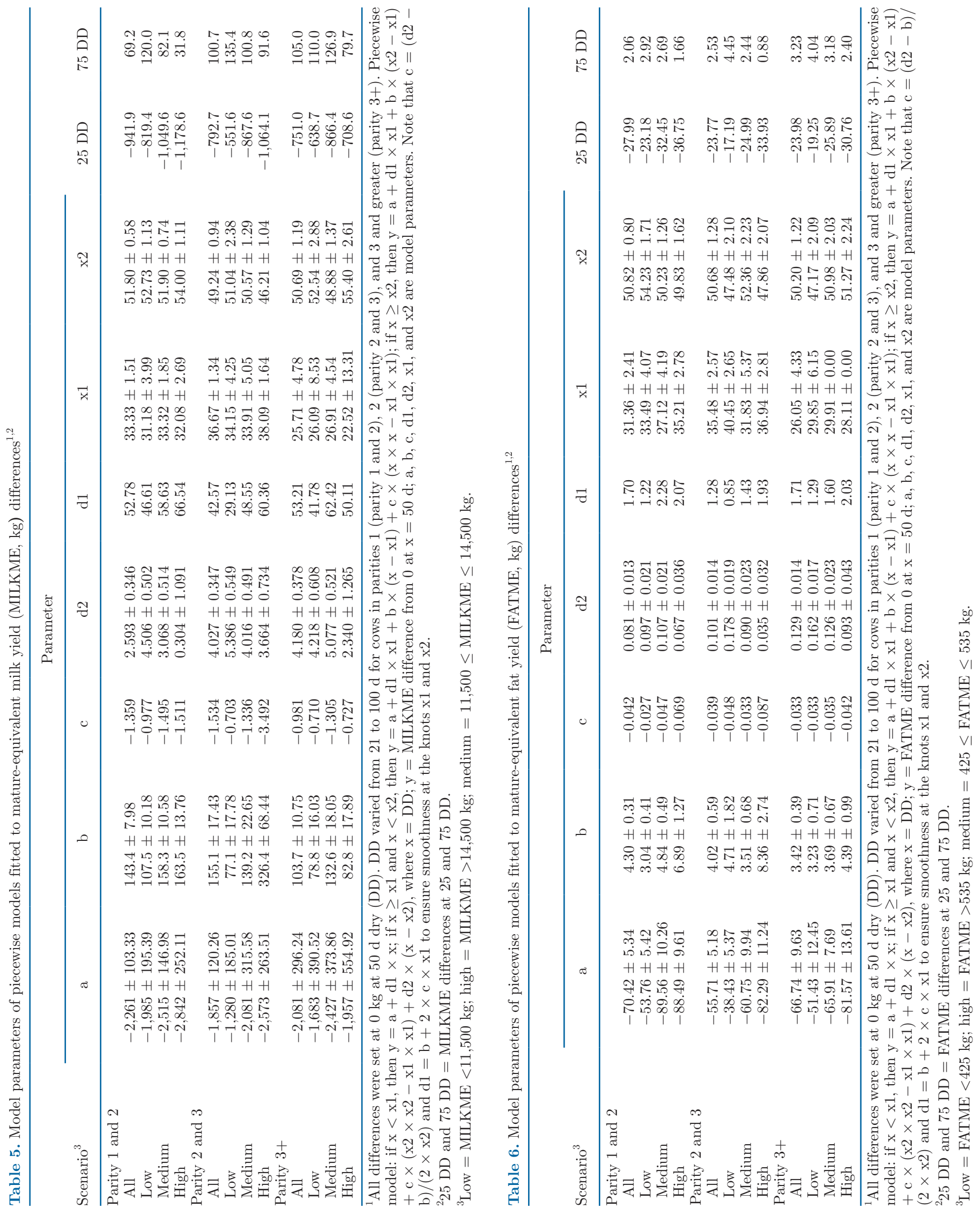


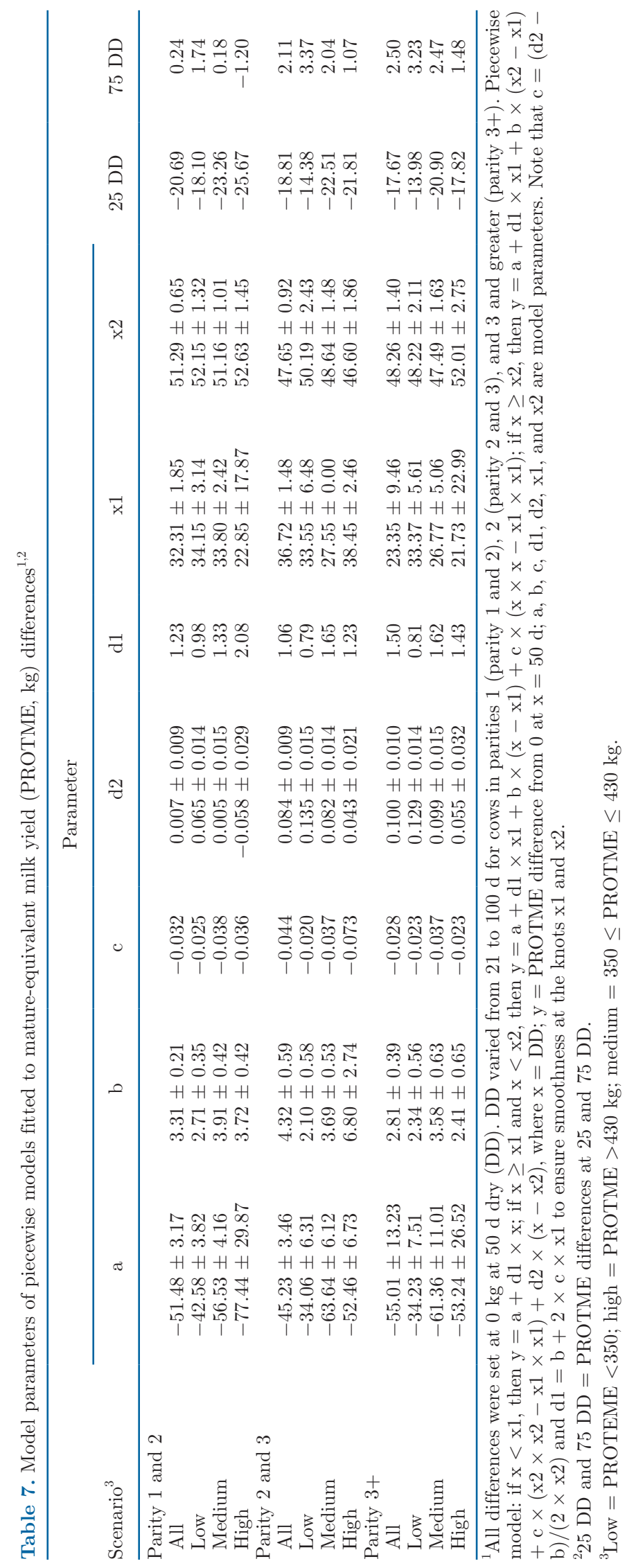

dictions from the piecewise models were visually quite similar to those from local regression.

The $\mathrm{R}^{2}$ of the piecewise models was $<2 \%$. The average RMSE of the residuals after piecewise modeling was reduced by less than $0.4 \%$ compared with the average RMSE of the residuals after control modeling.

\section{Yield Deviations from Literature Review}

Figure 2 shows 6 graphs of lactational yield deviations in the subsequent parity for changes in the DD, as found in our literature review. Milk yield deviations were reported in 38 studies, and both fat and protein yield deviations in 22 studies. References of these studies are given in Supplemental Figures S1 to S6 (https: //doi.org/10.3168/jds.2020-18363). The longest DD found in experimental studies was $71 \mathrm{~d}$; all other experimental studies had 61 or shorter DD. The longest DD in observational studies was $197 \mathrm{~d}$. Local regression lines showed deviations close to 0 around $60 \mathrm{DD}$. This was typically a consequence of the design of those studies.

Milk yield deviations in the subsequent lactations at 25 DD compared with 60 DD for experimental studies were $-1,002$ and $-711 \mathrm{~kg}$ for primiparous and multiparous cows, respectively. These deviations were -986 and $-833 \mathrm{~kg}$ for field studies and similar to our matureequivalent milk yield deviations of -942 and $-793 \mathrm{~kg}$ at $25 \mathrm{DD}$ (Table 5). Fat yield deviations at $25 \mathrm{DD}$ in experimental studies were -32 and $-25 \mathrm{~kg}$ for primiparous and multiparous cows. For field studies, these deviations were -40 and $-31 \mathrm{~kg}$. Our mature-equivalent fat yield deviations ( -28 and $-24 \mathrm{~kg}$ for par12 and par23) were closer to the deviations from experimental studies than from field studies (Table 6). Protein yield deviations at $25 \mathrm{DD}$ were $-28 \mathrm{~kg}$ for both primiparous and multiparous cows in experimental studies, and -31 and $-25 \mathrm{~kg}$ for observational studies. Our matureequivalent protein yield deviations at 25 DD were -21 and $-19 \mathrm{~kg}$ for par12 and par23, respectively (Table 7). Yield deviations at 25 DD across studies from the literature review and our study are therefore alike.

Figure 2 shows mostly negative yield deviations for field studies with DD longer than conventional (approximately $60 \mathrm{~d}$ ), whereas our study found mostly positive deviations for longer DD. Differences from 0 were small in both cases. Actual versus mature-equivalent yields, different DD where yield deviations are 0 , and different adjustment for covariates make direct comparisons impossible, however.

\section{DISCUSSION}

Our primary objective was to develop and validate equations that predict deviations in milk, fat, and pro- 

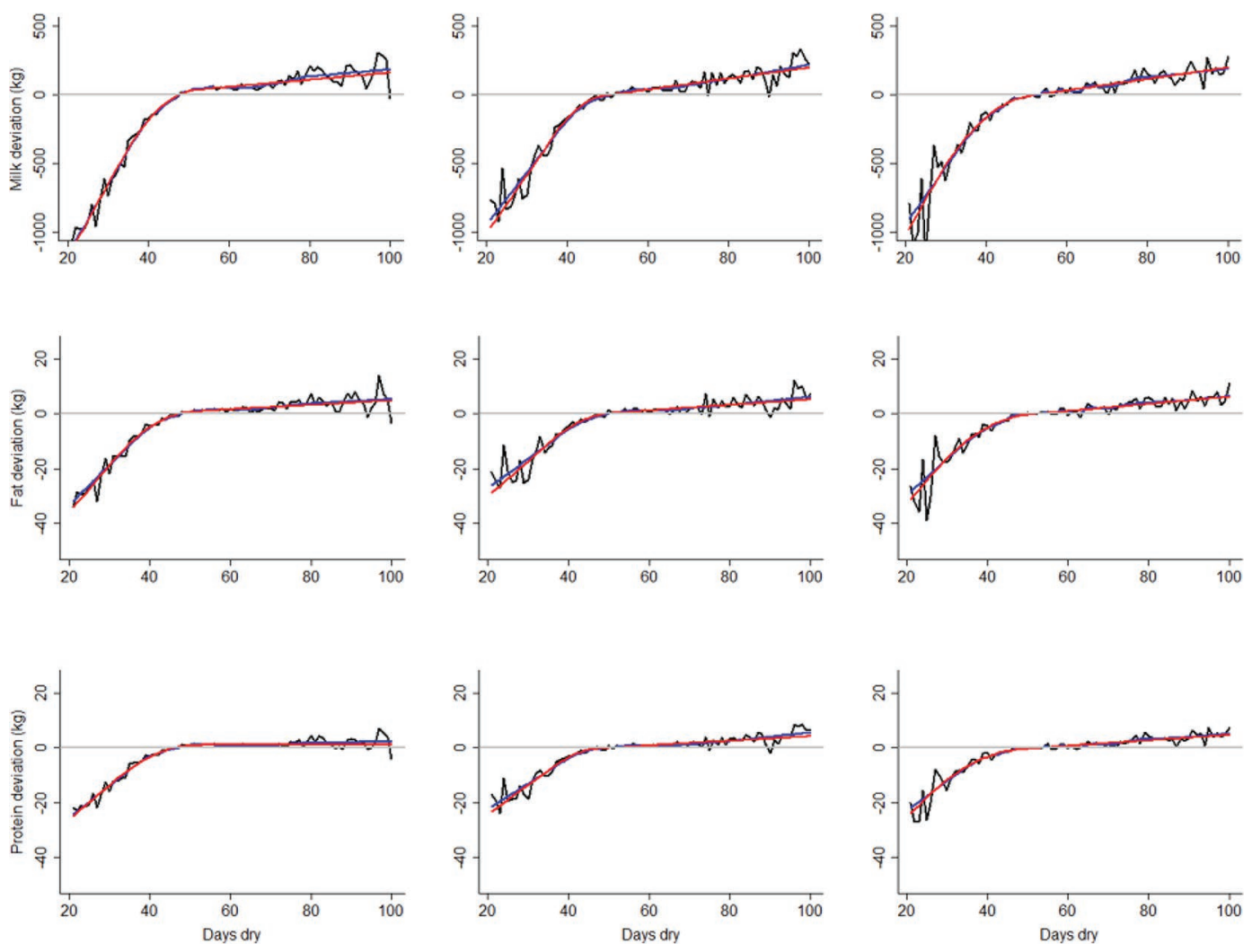

Figure 1. Mature-equivalent yield deviations $(\mathrm{kg} / 305 \mathrm{~d})$ for milk, fat, and protein yields. The leftmost 3 figures are for parity 1 and 2 , the middle 3 are for parity 2 and 3, and the rightmost 3 are for parity $3+$. Deviations per days dry (DD): average residuals of the control models (black), piecewise model (red), and locally estimated scatterplot smoothed lines (blue).

tein yield in the subsequent lactation as a function of DD. A secondary objective was to estimate how yield deviations in the subsequent lactation depended on yield and DD in the current lactation. Our model building was based on predictive modeling principles, which aim to predict a new value for a response variable from new values for predictor variables (Shmueli, 2010). In predictive modeling, greater emphasis is placed on obtaining predictive power and avoiding overfitting than on the statistical significance of predictor variables (Sainani, 2014; Lo et al., 2015). Predictive models may have low parsimony, because many predictors may be included (Shmueli, 2010; Sainani, 2014). However, our intent was also to obtain models that were easy to deploy.

\section{Variations in Dry Period Length in Practice}

Tables 1, 2, and 3 show variables associated with dry period length ranging from 21 to $100 \mathrm{DD}$. We also found DHIA records with dry period lengths less than $21 \mathrm{~d}$ or greater than $100 \mathrm{~d}$. Dry period lengths may vary because calving occurs earlier or later than anticipated - for example, because the date of conception is mistaken, or the gestation length is shorter than anticipated when cows experience heat stress (Fabris et al., 2019), have twin pregnancies (Echternkamp and Gregory, 1999), or carry female calves (Silva et al., 1992). Management associated with the shorter DD might therefore not have been optimal, such as the number of days in a pre-calving pen or days fed a closeup ration. Clinical mastitis may result in longer DD on $50 \%$ of farms in the US (USDA, 2016). Our data also showed that cows with longer dry period lengths had increased SCC at $180 \mathrm{~d}$ pregnant, approximately 100 $\mathrm{d}$ before the expected calving date. Cows with longer DD also produced less milk before dry-off. We do not know how much disease played a role in early dry-off decisions. Sick cows might benefit from a longer dry period.

Variations in dry period length planned further in advance of the dry-off date are often based on parity or milk yield (USDA, 2016). For example, first-parity cows may be given longer dry period lengths than older cows (Annen et al., 2004; Santschi et al., 2011a; Cermakova et al., 2014). Alternatively, first-lactation cows might receive shorter DD because of their greater persistency, and therefore greater milk yield late in lactation, than 

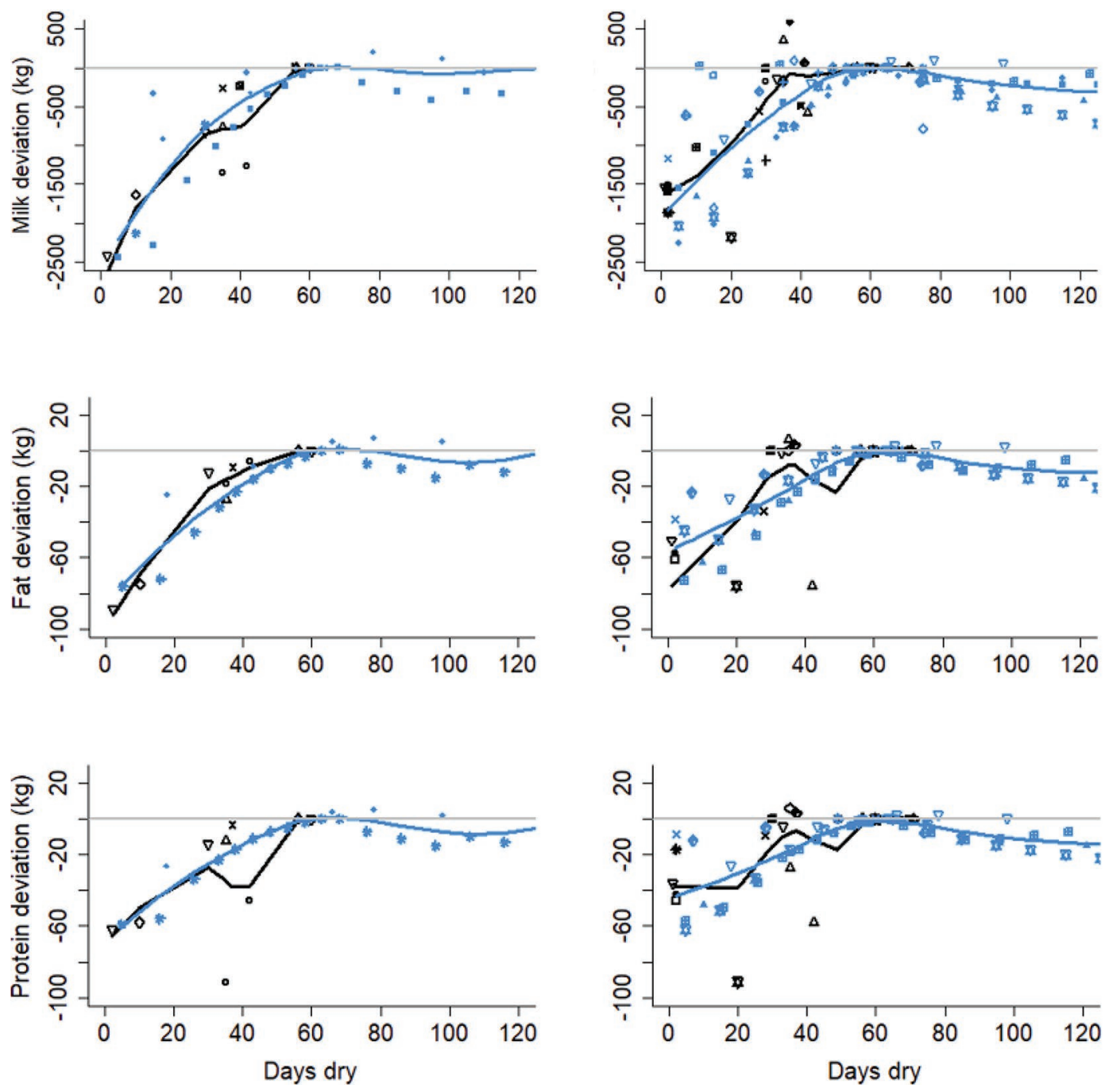

Figure 2. Associations between dry period length (days dry, DD) and lactational milk, fat, and protein yield deviations in the subsequent lactation as published in the literature. Experimental studies are in black and field studies are in blue. Yield deviations in subsequent lactation 2 are in the 3 figures on the left; yield deviations for greater lactations are in the 3 figures on the right. Deviations were calculated as the differences from the yield at the reference DD of each study. The reference DD was the conventional control DD (experimental studies) or the category that was the closest to the conventional $60 \mathrm{DD}$ (field studies). Patterns of yield deviations are illustrated by locally estimated scatterplot smoothed lines. References are given in Supplemental Figures S1-S6 (https://doi.org/10.3168/jds.2020-18363).

multiparous cows (Kuhn et al., 2007). The average dry period lengths in our data varied little with parity.

\section{Control for Covariates in the Current Lactation}

The addition of only mature-equivalent yields in the current lactation to the control models, as well as the random herd-season effect, reduced the large negative deviations for longer DD to smaller, but still often negative, yield deviations. Other covariates in the current lactation affected yield in the subsequent lactation as well. The addition to the control models of gestation length, days open, SCS at $180 \mathrm{~d}$ pregnant, and yield at $180 \mathrm{~d}$ pregnant further reduced the negative deviations for long DD. For all but one scenario, the average yield deviations generally became positive. The studies that provided yield deviations in Figure 2 all adjusted for yield in the current lactation. Two studies also included days open, and no studies included SCS near dry-off. One study included milk yield at $84 \mathrm{~d}$ before expected calving. It appears that the variables used for control modeling have substantial effects on the prediction of yield deviations from field data.

\section{Piecewise Modeling}

Discovery of realistic continuous equations to model the associations between dry period length, other co- 
variates, and yield deviations in the subsequent lactation was more challenging than expected. Early efforts included the fitting of a fourth-degree polynomial of DD with covariates. Yield deviations for long DD were exponentially ascending and could not be biologically justified (data not shown).

Our 3-part piecewise regression model fitted the observed yield deviations well and does not overfit. Further, the shapes of the local regression patterns through the field studies suggest that our piecewise model is an adequate functional form to model yield deviations as a function of DD. Too few experimental studies were available to discern otherwise. The addition of covariates to the piecewise model was often not successful because the model would not converge, or converged with warnings. For other cases, the model became apparently non-smooth when both knots were close together. We therefore decided to exclude covariates from the piecewise models. Inclusion of covariates in smooth continuous models to better predict yield losses for individual cows remains a topic for future investigation.

\section{Results of the Literature Review}

Yield deviations from the literature studies showed a pattern of greater negative yield deviations at shorter DD. Results varied widely, as was also the case for experimental studies. An experimental study revealed considerable variation in yield deviations among 13 herds (Santschi et al., 2011a). The validity of using field data to determine DD effects has been questioned (Bachman and Schairer, 2003; Grummer and Rastani, 2004). However, Kuhn and Hutchison (2005) provided evidence that the effects of dry period lengths on yield deviations could be estimated from field data with minor bias. We also did not find clear differences in the literature between yield patterns in experimental and field studies. Experimental studies allow for obtaining a deeper understanding of the physiological effects caused by variations in the dry period length, however.

\section{Effects of Dry Period Length on Yields in the Subsequent Lactation}

Although short dry period lengths have been shown to be economically advantageous under certain conditions (Bachman and Schairer, 2003; Kok et al., 2017b), conditions also exist wherein longer dry period lengths may be economically advantageous; for example, when milking capacity is a limiting factor, the milk quota is almost full, or cows are low-producing. Low-producing cows with long DD may have greater-than-recommended BCS at calving due to too much energy intake
(Friggens et al., 2004). However, body condition can be controlled by feeding strategies, primarily through formulation of diets from the mid-lactation nadir onward (Friggens et al., 2004). In an older experimental study, Sørensen and Enevoldsen (1991) found no evidence for a decrease in performance in the subsequent lactation when dry period length was increased from 7 to 10 wk. We found no experimental studies that investigated the effects of dry period lengths $>71 \mathrm{~d}$ on yields in the subsequent lactation. Because yield deviations were typically positive and increasing for long DD in our study, we did not find that conventional DD such as 60 $\mathrm{d}$ maximized yields in the subsequent lactation. No convincing evidence appears to exist that cows with long dry period lengths necessarily have decreased yield in the subsequent lactation when managed appropriately.

Our results provide some evidence that higher-yielding cows that have short dry period lengths have greater negative yield deviations in the subsequent lactation. Bach and Pont (2017) reported the same finding. Drying off high-yielding cows introduces unnecessary stress (Friggens et al., 2004). The risk of mastitis may also increase when high-yielding cows are dried off (Enevoldsen and Sørensen, 1992; Gott et al., 2017) due to increased udder pressure (Bertulat et al., 2013). Zhao et al. (2019) also offer other physiological mechanisms triggered by cessation of milk production, which suggest that high-producing cows may need a longer dry period for a complete renewal of their mammary gland. In practice, higher-yielding cows are sometimes given a shorter dry period length to have lower milk yields at dry-off. In our data, the high-yield scenarios had no more than $3 \mathrm{~d}$ shorter DD than the low-yield scenarios.

Higher-yielding cows also had smaller (positive) yield deviations for long dry period lengths than did lowproducing cows. Drying off high-yielding cows early is less rational economically, unless the cow is sick. Highyielding cows are less likely to have high body condition at dry-off, and are not likely to gain body condition during the dry period. The varying responses to short and long dry period length, depending on the level of yield in the current lactation, provide another rationale for individualized dry period lengths.

In our study, yield deviations following short dry period lengths were more negative for primiparous cows than multiparous cows. This finding is also reported in the literature (Annen et al., 2004; Santschi et al., 2011a; Cermakova et al., 2014) and is apparent in Figure 2. Short dry period lengths hamper first-lactation cows in completing their growth and replenishing reserves, which is manifested in more negative yield deviations in the second lactation (Friggens et al., 2004).

Also in our study, yield deviations following long dry period lengths were generally lower for primiparous 
cows than for multiparous cows, but still positive. On the other hand, field data in the literature (Figure 2) showed lower (and negative) yield deviations for multiparous cows.

Deviations in fat and protein yields are mostly associated with changes in milk yield. Reports on changes in fat content when DD decreased from conventional to short are mixed. Several authors found no changes in fat content (Watters et al., 2008; Klusmeyer et al., 2009; Santschi et al., 2011a), but others found an increase in fat content in the early part of the lactation (Rastani et al., 2005). Our results contrast with reports of no decrease in fat yield following a short dry period (Rastani et al., 2005; Pezeshki et al., 2007; Watters et al., 2008; Santschi et al., 2011a). Pezeshki et al. (2008) also reported a small decrease in fat yield.

Several authors have reported increases in protein concentration in response to short dry period lengths (Rastani et al., 2005; Watters et al., 2008; Santschi et al., 2011a) but not for every parity. In agreement with our results, a decrease in protein yield was also reported by Pezeshki et al. (2007). Santschi et al. (2011a) found no difference.

\section{Application}

Our choice of mature-equivalent yields as response variables implies that actual yield deviations associated with dry period lengths will be different. Younger cows produce less (USDA, 2016), but increased milking frequency can increase daily milk yield (Smith et al., 2002). A random sample of 500,000 of our records showed that the ratios of actual 305-d milk, fat, and protein yields of cows that completed their lactations to their mature-equivalent yields were $0.80,0.81$, and 0.82 for first lactation. For second through fourth lactations, these ratios were $0.91,0.91,0.93 ; 0.99,0.98$, 0.99; and 1.03, 1.02, and 1.02 for milk, fat, and protein, respectively. Ratios for fifth and sixth lactations were similar to those for the fourth lactation. Actual yield deviations due to various DD for subsequent second or third lactations are therefore smaller than those of mature-equivalent yields. We did not investigate whether certain stages of lactation showed greater yield deviations than others.

Prediction of yield deviations is only one of the factors that need to be included for economic optimization of the dry period length. Other major factors include at least additional yield in the current lactation (Kok et al., 2017a), dry cow management and labor, udder and overall health, fertility, and culling. Several studies have aimed to economically optimize dry period length, evaluating 2 (Santschi et al., 2011b; Heeren et al., 2014) or 3 (Kok et al., 2017b) dry period lengths. Older stud- ies have evaluated many dry period lengths (Dias and Allaire, 1982; O'Connor, and Oltenacu, 1988; Sørensen and Enevoldsen, 1991). Decision aids that include the current understanding of all factors affected by variations in dry period length are not commonly available.

\section{CONCLUSIONS}

We developed piecewise regression equations with 2 knots to predict mature-equivalent yield deviations in the subsequent lactation based on continuous DD. Controlling for confounding covariates was important. Predictions from piecewise equations were similar to predictions from local regression and fitted the data well. Predictions of mature-equivalent milk, fat, and protein yields were substantially lower when DD was shorter than 50 d. Predicted yields generally continued to increase with longer DD, such that no optimal DD for maximum yield was found. Yield deviations in the subsequent lactation were greater when the level of milk, fat, or protein yield in the current lactation was greater. Inclusion of covariates in piecewise models was not successful, however. The piecewise equations may be useful toward determining the optimal dry period length for individual cows.

\section{ACKNOWLEDGMENTS}

Pornpamol Pattamanont thanks the Department of Livestock Development, Ministry of Agriculture and Cooperatives, Thailand, and The Royal Thai Government (Bangkok) for financial support of her graduate studies. The authors thank 2 anonymous reviewers for their comments, which reshaped the original version of this paper, especially for the suggestion to explore piecewise regression modeling. The authors have not stated any conflicts of interest.

\section{REFERENCES}

Annen, E. L., R. J. Collier, M. A. McGuire, J. L. Vicini, J. M. Ballam, and M. J. Lormore. 2004. Effect of modified dry period lengths and bovine somatotropin on yield and composition of milk from dairy cows. J. Dairy Sci. 87:3746-3761. https://doi.org/10.3168/ jds.S0022-0302(04)73513-4.

Atashi, H., M. J. Zamiri, and M. Dadpasand. 2013. Association between dry period length and lactation performance, lactation curve, calf birth weight, and dystocia in Holstein dairy cows in Iran. J. Dairy Sci. 96:3632-3638. https://doi.org/10.3168/jds.2012 $-5943$.

Bach, A., and J. M. Pont. 2017. Interaction between level of production and dry period length on subsequent milking performance. J. Dairy Sci. 100(Suppl. 2):87.

Bachman, K. C., and M. L. Schairer. 2003. Invited review: Bovine studies on optimal lengths of dry periods. J. Dairy Sci. 86:30273037. https://doi.org/10.3168/jds.S0022-0302(03)73902-2.

Bertulat, S., C. Fischer-Tenhagen, and W. Heuwieser. 2015. A survey of drying-off practices on commercial dairy farms in northern 
Germany and a comparison to science-based recommendations. Vet. Rec. Open 2:e000068. https://doi.org/10.1136/vetreco-2014 -000068 .

Bertulat, S., C. Fischer-Tenhagen, V. Suthar, E. Möstl, N. Isaka, and W. Heuwieser. 2013. Measurement of fecal glucocorticoid metabolites and evaluation of udder characteristics to estimate stress after sudden dry-off in dairy cows with different milk yields. J. Dairy Sci. 96:3774-3787. https://doi.org/10.3168/jds.2012-6425.

Capuco, A. V., R. M. Akers, and J. J. Smith. 1997. Mammary growth in Holstein cows during the dry period: Quantification of nucleic acids and histology. J. Dairy Sci. 80:477-487. https://doi.org/10 .3168/jds.S0022-0302(97)75960-5.

Cermakova, J., V. Kudrna, M. Simeckova, A. Vyborna, P. Dolezal, and J. Illek. 2014. Comparison of shortened and conventional dry period management strategies. J. Dairy Sci. 97:5623-5636. https:/ /doi.org/10.3168/jds.2013-7499.

Dias, F. M., and F. R. Allaire. 1982. Dry period to maximize milk production over two consecutive lactations. J. Dairy Sci. 65:136-145. https://doi.org/10.3168/jds.S0022-0302(82)82162-0.

DRMS. 2018. DHI Glossary, February 2018. Dairy Records Management Systems, Raleigh, NC.

Echternkamp, S. E., and K. E. Gregory. 1999. Effects of twinning on gestation length, retained placenta, and dystocia. J. Anim. Sci. 77:39-47. https://doi.org/10.2527/1999.77139x.

Enevoldsen, C., and J. T. Sørensen. 1992. Effects of dry period length on clinical mastitis and other major clinical health disorders. J. Dairy Sci. 75:1007-1014. https://doi.org/10.3168/jds.S0022 -0302(92)77843-6.

Fabris, T. F., J. Laporta, A. L. Skibiel, F. N. Corra, B. D. Senn, S. E. Wohlgemuth, and G. E. Dahl. 2019. Effect of heat stress during early, late, and entire dry period on dairy cattle. J. Dairy Sci. 102:5647-5656. https://doi.org/10.3168/jds.2018-15721.

Foote, R. H. 1981. Factors affecting gestation length in dairy cattle. Theriogenology 15:553-559. https://doi.org/10.1016/0093 $-691 X(81) 90058-3$.

Friggens, N. C., J. B. Andersen, T. Larsen, O. Aaes, and R. J. Dewhurst. 2004. Priming the dairy cow for lactation: A review of dry cow feeding strategies. Anim. Res. 53:453-473. https://doi.org/10 .1051/animres:2004037.

Funk, D. A., A. E. Freeman, and P. J. Berger. 1987. Effects of previous days open, previous days dry, and present days open on lactation yield. J. Dairy Sci. 70:2366-2373.

Gill, G. S., and F. R. Allaire. 1976. Relationship of age at first calving, days open, days dry, and herdlife to a profit function for dairy cattle. J. Dairy Sci. 59:1131-1139. https://doi.org/10.3168/jds .S0022-0302(76)84333-0.

Gott, P. N., P. J. Rajala-Schultz, G. M. Schuenemann, K. L. Proudfoot, and J. S. Hogan. 2017. Effect of gradual or abrupt cessation of milking at dry off on milk yield and somatic cell score in the subsequent lactation. J. Dairy Sci. 100:2080-2089. https://doi .org/10.3168/jds.2016-11444.

Grummer, R. R, and R. R. Rastani. 2004. Why reevaluate dry period length? J. Dairy Sci. 87(E-suppl.):E77-E85.

Heeren, J. A. H., W. Steeneveld, and P. B. M. Berentsen. 2014. Economic comparison of a sixty day dry period with no dry period on Dutch dairy farms. Livest. Sci. 168:149-158. https://doi.org/10 .1016/j.livsci.2014.08.004.

Hossein-Zadeh, N. G., and A. Mohit. 2013. Effect of dry period length on the subsequent production and reproduction in Holstein cows. Span. J. Agric. Res. 11:100-108. https://doi.org/10.5424/sjar/ 2013111-3165.

Klusmeyer, T. H., A. C. Fitzgerald, A. C. Fabellar, J. M. Ballam, R. A. Cady, and J. L. Vicini. 2009. Effect of recombinant bovine somatotropin and a shortened or no dry period on the performance of lactating dairy cows. J. Dairy Sci. 92:5503-5511. https://doi .org/10.3168/jds.2009-2390.

Kok, A., A. T. M. van Knegsel, C. E. van Middelaar, B. Engel, H. Hogeveen, B. Kemp, and I. J. M. de Boer. 2017a. Effect of dry period length on milk yield over multiple lactations. J. Dairy Sci. 100:739-749. https://doi.org/10.3168/jds.2016-10963.
Kok, A., C. E. van Middelaar, P. F. Mostert, A. T. M. van Knegsel, B. Kemp, I. J. M. de Boer, and H. Hogeveen. 2017b. Effects of dry period length on production, cash flows and greenhouse gas emissions of the dairy herd: A dynamic stochastic simulation model. PLoS One 12:e0187101. https://doi.org/10.1371/journal .pone. 0187101.

Kuhn, M. T., and J. L. Hutchison. 2005. Methodology for estimation of days dry effects. J. Dairy Sci. 88:1499-1508. https://doi.org/10 .3168/jds.S0022-0302(05)72818-6.

Kuhn, M. T., J. L. Hutchison, and H. D. Norman. 2005a. Minimum days dry to maximize milk yield in subsequent lactation. Anim. Res. 54:351-367. https://doi.org/10.1051/animres:2005031.

Kuhn, M. T., J. L. Hutchison, and H. D. Norman. 2005b. Characterization of days dry for United States Holsteins. J. Dairy Sci. 88:1147-1155. https://doi.org/10.3168/jds.S0022-0302(05)72781 $-8$.

Kuhn, M. T., J. L. Hutchison, and H. D. Norman. 2007. Dry period length in US Jerseys: Characterization and effects on performance. J. Dairy Sci. 90:2069-2081. https://doi.org/10.3168/jds.2006-702.

Lactanet. 2020. 2019 Western Canada Progress Report. Accessed Jul. 14, 2020. https://issuu.com/lactanet/docs/west_final.

Lo, A., H. Chernoff, T. Zheng, and S. H. Lo. 2015. Why significant variables aren't automatically good predictors. Proc. Natl. Acad. Sci. USA 112:13892-13897. https://doi.org/10.1073/pnas.1518285112.

Mur-Novales, R., F. Lopez-Gatius, P. M. Fricke, and V. E. Cabrera. 2018. An economic evaluation of management strategies to mitigate the negative effect of twinning in dairy herds. J. Dairy Sci. 101:8335-8349. https://doi.org/10.3168/jds.2018-14400.

O'Connor, J. J. Jr., and P. A. Oltenacu. 1988. Determination of optimum drying off time for dairy cows using decision analysis and computer simulation. J. Dairy Sci. 71:3080-3091. https://doi.org/ 10.3168/jds.S0022-0302(88)79908-7.

Pezeshki, A., J. Mehrzad, G. R. Ghorbani, B. DeSpiegeleer, R. J. Collier, and C. Burvenich. 2008. Effect of dry period length reduction to 28 days on the performance of multiparous dairy cows in the subsequent lactation. Can. J. Anim. Sci. 88:449-456.

Pezeshki, A., J. Mehrzad, G. R. Ghorbani, H. R. Rahmani, R. J. Collier, and C. Burvenich. 2007. Effects of short dry periods on performance and metabolic status in Holstein dairy cows. J. Dairy Sci. 90:5531-5541. https://doi.org/10.3168/jds.2007-0359.

Pinedo, P., C. Risco, and P. Melendez. 2011. A retrospective study on the association between different lengths of the dry period and subclinical mastitis, milk yield, reproductive performance, and culling in Chilean dairy cows. J. Dairy Sci. 94:106-115. https:// doi.org/10.3168/jds.2010-3141.

R Core Team. 2019. R: A Language and Environment for Statistical Computing. R Foundation for Statistical Computing, Vienna, Austria. https://www.R-project.org/.

Rastani, R. R., R. R. Grummer, S. J. Bertics, A. Gümen, M. C. Wiltbank, D. G. Mashek, and M. C. Schwab. 2005. Reducing dry period length to simplify feeding transition cows: Milk production, energy balance, and metabolic profiles. J. Dairy Sci. 88:1004-1014. https://doi.org/10.3168/jds.S0022-0302(05)72768-5.

Sainani, K. L. 2014. Explanatory versus predictive modeling. PM R. 6:841-844. https://doi.org/10.1016/j.pmrj.2014.08.941.

Santschi, D. E., D. M. Lefebvre, R. I. Cue, C. L. Girard, and D. Pellerin. 2011a. Complete-lactation milk and component yields following a short (35-d) or a conventional (60-d) dry period management strategy in commercial Holstein herds. J. Dairy Sci. 94:2302-2311. https://doi.org/10.3168/jds.2010-3594.

Santschi, D. E., D. M. Lefebvre, R. I. Cue, C. L. Girard, and D. Pellerin. 2011b. Economic effect of short (35-d) compared with conventional (60-d) dry period management in commercial Canadian Holstein herds. J. Dairy Sci. 94:4734-4743. https://doi.org/ 10.3168/jds.2010-3596.

SAS Institute Inc. 2013. SAS/STAT 13.1 User's Guide. SAS Institute Inc., Cary, NC. https://support.sas.com/documentation/ onlinedoc/stat/131/nlin.pdf.

Shmueli, G. 2010. To explain or to predict? Stat. Sci. 25:289-310. https://doi.org/10.1214/10-STS330. 
Silva, H. M., C. J. Wilcox, W. W. Thatcher, R. B. Becker, and D. Morse. 1992. Factors affecting days open, gestation length, and calving interval in Florida dairy cattle. J. Dairy Sci. 75:288-293. https://doi.org/10.3168/jds.S0022-0302(92)77764-9.

Smith, J. W., L. O. Ely, W. M. Graves, and W. D. Gilson. 2002. Effect of milking frequency on DHI performance measures. J. Dairy Sci. 85:3526-3533. https://doi.org/10.3168/jds.S0022-0302(02)74442 $-1$.

Sørensen, J. T., and C. Enevoldsen. 1991. Effect of dry period length on milk production in subsequent lactation. J. Dairy Sci. 74:12771283. https://doi.org/10.3168/jds.S0022-0302(91)78283-0.

Steeneveld, W., A. T. M. van Knegsel, G. J. Remmelink, B. Kemp, J. C. M. Vernooij, and H. Hogeveen. 2014. Cow characteristics and their association with production performance with different dry period lengths. J. Dairy Sci. 97:4922-4931. https://doi.org/10 $.3168 /$ jds.2013-7859.

USDA. 2016. Dairy 2014: Milk quality, milking procedures, and mastitis in the United States, 2014. \#704.0916. USDA-APHIS-VSCEAH-NAHMS, Fort Collins, CO.

van Knegsel, A. T. M., S. G. A. van der Drift, J. Cermakova, and B. Kemp. 2013. Effects of shortening the dry period of dairy cows on milk production, energy balance, health, and fertility: A systematic review. Vet. J. 198:707-713. https://doi.org/10.1016/j.tvjl .2013 .10 .005
Watters, R. D., J. N. Guenther, A. E. Brickner, R. R. Rastani, P. M. Crump, P. W. Clark, and R. R. Grummer. 2008. Effects of dry period length on milk production and health of dairy cattle. J. Dairy Sci. 91:2595-2603. https://doi.org/10.3168/jds.2007-0615.

Weber, C., B. Losand, A. Tuchscherer, F. Rehbock, E. Blum, W. Yang, R. M. Bruckmaier, P. Sanftleben, and H. M. Hammon. 2015. Effects of dry period length on milk production, body condition, metabolites, and hepatic glucose metabolism in dairy cows. J. Dairy Sci. 98:1772-1785. https://doi.org/10.3168/jds.2014-8598.

Zhao, X., B. Ponchon, S. Lanctôt, and P. Lacasse. 2019. Invited review: Accelerating mammary gland involution after drying-off in dairy cattle. J. Dairy Sci. 102:6701-6717. https://doi.org/10.3168/ jds.2019-16377.

\section{ORCIDS}

P. Pattamanont (i) https://orcid.org/0000-0001-5391-3581

M. I. Marcondes (ำ https://orcid.org/0000-0003-4843-2809

J. S. Clay @ https://orcid.org/0000-0001-7273-225X

A. Bach $\odot$ https://orcid.org/0000-0001-6804-2002

A. De Vries (ํ) https://orcid.org/0000-0003-4511-0388 